\title{
Identification of Tree Species from the Peruvian Tropical Amazon "Selva Central" Forests According to Wood Anatomy
}

\author{
Cassiana A. Ferreira, ${ }^{\mathrm{a}, *}$ Janet G. Inga, ${ }^{\mathrm{a}}$ Osir D. Vidal, ${ }^{\mathrm{a}}$ Walter E. Goytendia, ${ }^{\mathrm{a}}$ \\ Sthefany M. Moya, ${ }^{\mathrm{a}}$ Thonny B. Centeno, ${ }^{\mathrm{a}}$ Andrés Vélez, ${ }^{\mathrm{b}}$ Daniel Gamarra, ${ }^{\mathrm{a}}$ and \\ Mario Tomazello-Filho ${ }^{\mathrm{c}}$
}

\begin{abstract}
The "Selva Central" of Peru is characterized by its forest species richness that produces quality wood for countless uses. Therefore, it is necessary to identify the wood and its macroscopic anatomy, which is an important tool for the botanical identification of tree species. For this purpose, 13 sawmills located in 3 provinces were selected that exploit several tree species of "Selva Central". Sampling of representative woods was carried out, identified by common names and, in the laboratory, they were polished, examined, and grouped by the similarity of the macroscopic anatomical structure, leading to the tree species identification. Twenty tree species were identified, belonging to 17 genera, with emphasis on the Lauraceae and Fabaceae families. However, Moraceae, Meliaceae, Lecythidaceae, Euphorbiaceae, Bignoniaceae, Myristicaceae, Combretaceae, and Burseraceae families were also identified. The anatomical structures of all the identified tree species were described, transversal and longitudinal tangential cross section images were collected, and a species identification key was constructed. The implications and importance of tree species identification via wood anatomy were discussed, in terms of controlling forest exploitation, traceability of the production chain, and the future development of an artificial intelligence tree-species identification method.
\end{abstract}

Keywords: Tropical wood species; Wood identification; Amazon tree species; Peruvian Forest.

Contact information: a: Laboratory of Wood Anatomy, Continental University, Av San Carlos 1980,

Huancayo 12000 Perú; b: National University of Colombia, Medellin Colombia; c: São Paulo University, São Paulo 05508-060 Brazil; *Corresponding author: cassianaaf@gmail.com

\section{INTRODUCTION}

The International Tropical Timber Organization indicates that more than 2.5 billion cubic meters of tropical timber was traded worldwide in 2020 (Claudon 2020). Several factors, including the Covid-19 pandemic and economic-social impacts resulted in a $17 \%$ reduction of the wood volume compared to 2019. The considerable wood volume traded in the last 2 years, as well as in a longer series of historical statistical data, shows the need for efficient regulation and inspection of wood origins and provenance, reflecting on the benefits of sustainability and the maintenance of tropical forest biodiversity.

The government of Peru, in a document compiled by the National Strategy for Forests and Climate Change (ENBCC), indicates there are 100 million hectares of forests, representing $80 \%$ of its area. The forest area of Peru is 72 million hectares, with 69 million hectares of Amazonian forests, 4 million hectares of seasonally dry forests, and 200,000 ha of Andean forests. Statistics indicate a reduction in the area of the Amazonian forests from 2001 to 2013 by 1.5 million hectares, according to reports of the National Forest 
Conservation Program for Climate Change Mitigation.

Statistics guide the application of strategic measures for the protection and conservation of natural forest areas, in partnership with the International Union for the Conservation of Nature (IUCN) and in compliance with the terms of the Convention on International Trade in Endangered Species (CITES) (SERFOR 2016). These initiatives that are applied to control illegal logging and informal trade in tropical timber are necessary and essential, concurrently with the application of effective sustainable forest management practices (Lima et al. 2018).

In order to achieve the objectives of applying effective control measures and verifying the traceability of the origins of wood, i.e., from exploration, commercialization, and usage, efficient tools are needed, which include the forensic identification of wood species (Dormontt et al. 2015; Vlam et al. 2018).

According to the Forestry and Wild Fauna Yearbook, a total of $2631.78 \mathrm{~m}^{3}$ of sawn wood was subject to intervention by the inspection institutions in 2019, mentioning the following tree species: Cedrelinga cateniformis (Ducke) Ducke (Fabaceae) (capirona or tornillo), Cedrela spp. L. (Meliaceae) (cedar), and Ficus insipida Willd (Moraceae) (oje) (SERFOR 2020a).

The correct and safe botanical identification of tree species at the various stages of the traceability process, by examining vegetative organisms, e.g., leaves, and the wood, constitute one of the primary limitations in the control of the extraction, transportation, trade, and illegal usage of timber.

Complementary aspects are related to the application of common names to wood species during the entire production chain, which leads to serious misidentification, either intentional or involuntary. In addition, there are numerous difficulties and restrictions to local access for the collection and examination of the wood, as well as the scarceness of competence and specialists capable of plant species identification, taxonomists, and wood anatomists.

There are several efficient methods for the identification of tree species by their wood, with the classic and most widespread methods utilizing the general characteristics (organoleptic) and the macro-microscopic wood anatomical structure diversity. This methodology presents a high degree of assertiveness and reliability in the results, if supported by qualified personnel and physical wood collection is available (Hoadley 1990; Wheeler and Baas 1998; Carlquist 2001; Gasson 2011; Gasson et al. 2011; Dormontt et al. 2015; Ruffinatto et al. 2015; Duarte et al. 2021; Santini Jr. et al. 2021).

The macro and microscopic wood anatomy has a wide application and is not exclusive for the taxonomy and identification of tree species. These methods are important in the study of plant physiology, ecology, and even wood technology, i.e., its use, applications, etc. In the last few decades, new methodologies for tree species identification via wood analysis have been developed, which include digital image databases, the application of artificial intelligence principles, NIR spectra evaluation, etc. However, these methods mandatorily require scientific validation by examining the anatomical structure of the wood, which must be previously identified (Dormontt et al. 2015). This is the initial and basic stage for the application of digital wood images for species identification using artificial intelligence (Fabijanska, et al. 2021). The present work aims at the botanical identification of the primary tree species, recognized as wood producers, found in three provinces of the Central Peruvian Forest, and applying the classical methodology based on the field collection followed by the analysis and description of wood anatomical structure. 


\section{EXPERIMENTAL}

\section{Peruvian "Selva Central" and the Tropical Tree Wood Species Surveyed}

The Peruvian "Selva Central" distinguishes the climate of the "Selva Alta "and the "Selva Baja", which are both a tropical climate. Located in the high forest are the provinces of Chanchamayo and Satipo (Junín province), which together with Oxapampa (Pasco province) make up the so-called "Selva Central". The province of Chanchamayo has a tropical climate that is warm, humid, and rainy. The average annual temperature ranges from 18 to $30{ }^{\circ} \mathrm{C}$ and the precipitation is $2000 \mathrm{~mm}$ per year. Satipo has a tropical climate (classified as Af according to the Koppen system) located at $627 \mathrm{~m}$ above sea level, with an annual rainfall of $2446 \mathrm{~mm}$ per year and an average temperature of $20.7^{\circ} \mathrm{C}$. Oxapampa is located at $1810 \mathrm{~m}$ above sea level, with a warm and temperate climate. The climate in Oxapampa is classified as $\mathrm{Cfb}$ according to the Koppen system, and the average temperature is $14.6{ }^{\circ} \mathrm{C}$, with an annual rainfall of $3474 \mathrm{~mm}$ per year (Ministerio del ambiente - Classification Map of Peru, 2020).
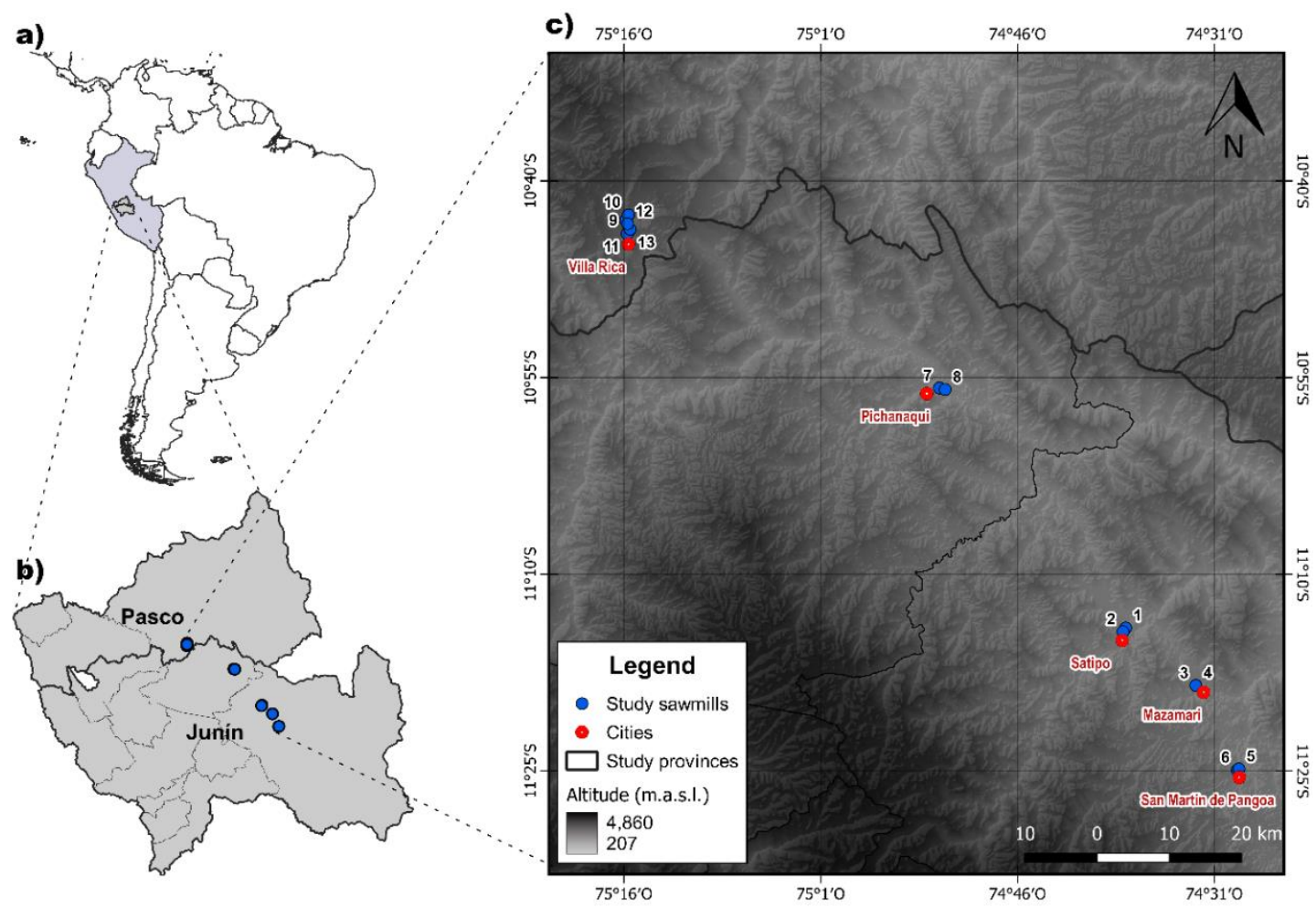

Fig. 1. Peruvian "Selva Central" in the Satipo, Chanchamayo, and Oxapampa Provinces and the location of the sawmill companies: Province of Satipo (Distrito of Satipo: 1. Nematsa,

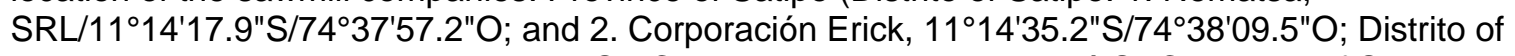
Mazamari: 3. Industrias de la Madera SA.C; and 4. Machu Picchu Perú SAC; Distrito of S.M. de Pangoa: 5. Maderas Pangoa, $11^{\circ} 25^{\prime} 02.5^{\prime \prime S} / 74^{\circ} 29^{\prime} 19.7^{\prime \prime O}$; and 6. Maderera Alexis, $11^{\circ} 25^{\prime} 08.3^{\prime \prime S} / 74^{\circ} 29^{\prime 2} 27.4^{\prime \prime O}$ ); Province of Chanchamayo (Distrito of Pichanaqui: 7. Forestal Luis Solarzano EIRL, $10^{\circ} 55^{\prime} 59.3^{\prime \prime S} / 74^{\circ} 52^{\prime} 08.6 " O$; and 8. Industrial Maderera Roble, $10^{\circ} 56^{\prime} 06.5^{\prime S} \mathrm{~S} / 74^{\circ} 51^{\prime} 42.8^{\prime \prime} \mathrm{O}$; ; and Province of Oxapampa (Distrito of Villa Rica: 9. Maderera Rainforest Arbocco, $10^{\circ} 43^{\prime} 27.6 " \mathrm{~S} / 75^{\circ} 15^{\prime} 50.5^{\prime \prime} \mathrm{O} ; 10$. Tulpay y Vidalon, $10^{\circ} 43^{\prime} 20.2^{\prime \prime S} / 75^{\circ} 15^{\prime} 49.4^{\prime \prime O}$; 11. Ind. Forestales Villa Rica SAC, 1044'6.4"S/75¹5'51.9"O; 12. Mavir Forestales EIRL, $10^{\circ} 43^{\prime} 36.4^{\prime \prime S} / 75^{\circ} 15^{\prime} 47.2 " \mathrm{O}$; and 13. Industrias Villa Rica IRL, $\left.10^{\circ} 44^{\prime} 0.9^{\prime \prime S} / 75^{\circ} 15^{\prime} 51.2^{\prime \prime O}\right)$ 
For the scientific surveys, 13 sawmill companies that exploited and processed wood from tropical tree species in the Peruvian "Selva Central" were selected. These sawmills were located in the 3 Peruvian provinces: Satipo (districts of Satipo, Mazamari, S.M. de Pangoa), Chanchamayo (district Pichanaqui), and Oxapampa (district Villa Rica). These sawmills utilize trees from the natural forests of native communities and from forestry concessions, as well as under contracts supervised by the National Forestry and Wildlife Service (SERFOR). In the sawmill courtyards, the tree trunks are split into sawn wood of different dimensions, using an industrial band saw, and are stored in wooden sheds or outside as the first stage of its natural drying. In the company yard, a representative inspection of the tree species exploited was performed, followed by the selection, and cutting of wood samples. At the same time, the correspondent common names and primary wood applications were collected. The wood samples were identified by their common names and stored in plastic bags for transportation to the laboratory.

\section{Wood Samples Preparation, Macroscopic Analysis, and Species Identification}

The wood samples, previously identified and grouped by common names, were kept in the laboratory to allow for natural drying. Then, the wood specimens were cut into $5 \mathrm{~cm} \times 5 \mathrm{~cm} \times 5 \mathrm{~cm}$ (edge) samples, and then oriented in cross transversal and radialtangential longitudinal sections. The wood samples were polished with sandpaper sheets ranging from 80 grain to 1500 grain, and then cleaned with air spray. Macroscopic anatomical analysis was performed with the aid of a 10x hand lens (Coradin and Muñiz 1992). Wood sections were observed using a Leica 9Si stereomicroscope (10x) coupled with a digital camera connected to a computer to obtain high quality images of the macroscopic anatomical structure. The species identification was based on the IAWA Standards, Macroscopic Identification of Commercial Woods, and specialized literature (Wheeler et al. 1989; Coradin and Muñiz 1992; Custodio 2005; Maguiña 2008; Coradin et al. 2010; Zenid and Ceccantini 2012; Custodio 2015; Oliva and Zerpa 2018). The wood samples were deposited at the Wood Collection portion of the Wood Anatomy Laboratory, at the Continental University, Campus Huancayo, Huancayo municipality, Junín department, Peru.

\section{RESULTS AND DISCUSSION}

\section{Wood Species Trees Identified by Their Anatomical Structure}

The wood samples collected from the 13 sawmill companies that were analyzed for their organoleptic features and macroscopic anatomical structure, as well as supported by numerous literature sources, allowed for the identification of 20 tree species (as shown in Table 1) (Mallque and Kikata, 1994; Custodio 2005; Maguiña 2008; Cassimiro 2011; Custodio 2015; Oliva and Zerpa 2018; Lava et al. 2019; SERFOR 2020b; Santini Jr. et al. 2021). These 20 species were reported to exist in the "Selva Central" of the 3 Peruvian provinces and are characterized by their dimensions, frequency, and wood quality. This group of 20 tropical forest tree species corresponded to the primary botanical families, mentioning the Moraceae and Meliaceae (10\%), Fabaceae (15\%), and Lauraceae (30\%), with the Lecythidaceae, Euphorbiaceae, Bignoniaceae, Myristicaceae, Combretaceae, and Burseraceae families also being identified (5\% each). The genus Ocotea had the largest number of species, with three species. 
Table 1. Tree Species Identified and Their Common Names and Families

\begin{tabular}{|c|c|c|c|}
\hline No & Scientific Name & Common Name & Family \\
\hline I & Aniba panurensis (Meissn.) Mez & Moena blanca & Lauraceae \\
\hline II & Brosimum alicastrum Swartz & Congona & Moraceae \\
\hline III & Cariniana spp. Casar & Cachimbo & Lecythidaceae \\
\hline IV & Cedrela fissilis Vell. & Cedro agua & Meliaceae \\
\hline V & Cedrela odorata L. & Cedro & Meliaceae \\
\hline VI & Enterolobium schomburgkii (Bentham) Bentham & Yarahuisca & Fabaceae \\
\hline VII & Hura creptans L. & Cathaua & Euphorbiaceae \\
\hline VIII & Jacaranda copaia (Aublet) D. Don & Palo Carton & Bignoniaceae \\
\hline IX & Matisia bicolor Ducke & Sapote & Malvaceae \\
\hline X & Ocotea spp. Aubl. & Sachapalta & Lauraceae \\
\hline XI & Ocotea aciphylla (Nees \& Mart) Mez & Moena amarilla & Lauraceae \\
\hline XII & Ocotea leucoxylon (Swartz) de Lanessan & Moena rosada & Lauraceae \\
\hline XIII & Otoba spp. (A.DC.) H.Karst. & Cumala & Myristicaceae \\
\hline XIV & Persea areolatocostae (C. K. Allen) van der Werff & Moena amarilla & Lauraceae \\
\hline XV & Pleurothyrium cuneifolium Nees & Moena negra & Lauraceae \\
\hline XVI & Poulsenia armata (Miq.) Standley & Lanchan & Moraceae \\
\hline XVII & Pterocarpus spp. Jacq. & Palo sangre & Fabaceae \\
\hline XVIII & Schizolobium amazonicum Huber ex Ducke & Pino chunchu & Fabaceae \\
\hline IXX & Terminalia oblonga (Ruiz \& Pavon) Stuedel & Yacushapana & Combretaceae \\
\hline XX & Tetragastris altissima (Aublet) Swart & Pochotaroque & Burseraceae \\
\hline
\end{tabular}

In the context of the Peruvian forest, specifically in the province forests, the primary tree species represented by the families, scientific name, and common names, are as follows: 1) Fabaceae: Enterolobium schomburgkii - yarahuisca, pashaco, oreja de negro, and vilco; Pterocarpus spp. - palo sangre and palisangre Amarillo; Schizolobium amazonicum - pino chunchu; and 2) Lauraceae: Aniba panurensis - moena blanca and moena alcafor; Ocotea spp. - sachapalta, moena, and moena amarilla; O. aciphylla moena amarilla, alcanfor moena, canela moena, canelón, plata moena, roble amarillo, and tinchi; O. leucoxylon - moena and moena rosada; Persea areolatocostae - moena amarilla; Pleurothyrium cuneifolium - moena negra and moena. Other important tree species were found (listed by family, scientific name, and common names), as follows: 1) Meliaceae: Cedrela fissilis - cedro agua, cedro blanco, cedro huasca, and largarto cedro; C. odorata cedro, cedro colorado, cedro restinga, and kanu); 2) Moraceae: Brosimum alicastrum congona and machinga; Poulsenia armata - lanchan and yanchama; 3) Lecythidaceae: Cariniana spp. - cachimbo: 4) Euphorbiaceae: Hura creptans - cathaua and cathaua amarilla; 5) Bignoniaceae: Jacaranda copaia - palo carton, malecon, carapachu, ishtapi, and palo lapiz; 6) Malvaceae: Matisia bicolor - sapote and machin sapote; 7) Myristicaceae: Otoba spp. - cumala, cumala aguanillo, banderilla, and caobilla; 8) Combretaceae: Terminalia oblonga - yacushapana; and 9) Burseraceae: Tetragastris altissima - pochotaroque, hualtaco de selva, and copal. 


\section{Tree Species General Dendrological Features}

Belonging to the Fabaceae family, Enterolobium schomburgkii trees are found in Central and Southeastern Amazon at an altitude of $290 \mathrm{~m}$ and presented as a straight and cylindrical stem up to $30 \mathrm{~m}$ high. The outer bark is brown to reddish brown, moderate sapopemas, with lenticels, and often sheds in small, irregular plates. In addition, it has stratified inner bark with yellowish brown bands interspersed with orange pink bands, frequently with translucent yellowish sap. The Pterocarpus spp. trees reach 20 to $35 \mathrm{~m}$ tall and have a 40 to $90 \mathrm{~cm}$ diameter trunk and are found in Amazon tropical forests with high rainfall, at a $700 \mathrm{~m}$ altitude, in clay to silty fertile, well-drained soils, sometimes with high stoniness. The outer bark lenticels are light brown in color in horizontal rows; the inner bark is thick and homogeneous, with a pale pink color and red sap secretions and a characteristic firewood smell. Schizolobium amazonicum trees are $30 \mathrm{~m}$ tall, with a trunk diameter up to $100 \mathrm{~cm}$, and are straight and slightly conical. They are found primarily below $1200 \mathrm{~m}$ above sea level, with high and constant rainfall, and marked dry season. In addition, they are found in sandy to silty soils, with medium to high fertility that is well drained with low stoniness. Fast-growing tree species are found in gaps in the primary forests and in early and late secondary forests. Their outer bark is 2 to $4 \mathrm{~cm}$ thickness and has a greyish brown color with a compact and inner bark white and smooth texture. (Reynel et al. 2003; Cassimiro 2011; Osinfor 2018; Mendoza et al. 2020; SERFOR 2020b).

The Lauraceae family is represented by Aniba panurensis tree, which are 15 to 30 $\mathrm{m}$ high, have a 25 to $80 \mathrm{~cm}$ trunk diameter and a cylindrical stem. They are found primarily 200 to $1000 \mathrm{~m}$ above sea level. Their outer bark is lenticular, with a bright yellow color to light reddish brown when oxidized and has elongated circular lenticels 3 to $5 \mathrm{~mm}$ in horizontal rows. The inner bark is homogeneous, a yellowish color, which turns to dark brown after oxidization, and a strong fragrant odor (Linares and Ramos 2011; Penagos and Madriñan 2015). The Ocotea spp. tree species has a height of 15 to $30 \mathrm{~m}$, a trunk diameter of 20 to $40 \mathrm{~cm}$, with a cylindrical stem. The outer bark is yellow brown color with lenticels in horizontal rows; the inner bark is homogeneous with a whitish yellow brown color, with orange inclusions and rapidly oxidizes to dark brown. In addition, it has a strong and characteristic odor similar to cinnamon (Linares and Ramos 2011). Ocotea aciphylla trees reach up to $35 \mathrm{~m}$ tall and have a trunk diameter of 60 to $80 \mathrm{~cm}$ and are straight and cylindrical. The brown outer bark can dehiscence in longitudinal plates exposing white or yellowish lenticels; the yellow-white inner bark oxidizes to a light brown, with orange inclusions with a characteristic cinnamon odor (OSINFOR 2017; SERFOR 2020b). Ocotea leucoxylon trees reach up to a 20 to $30 \mathrm{~m}$ height and with a trunk diameter of 40 to $70 \mathrm{~cm}$ and is found 0 to $500 \mathrm{~m}$ above sea level Departments of Loreto and Huanuco, Peru, with a wide distribution in the Amazonica and Atlantic forests (Brazil). The leaves are in elliptical sheets, 10 to $17 \mathrm{~cm}$ and 3 to $7 \mathrm{~cm}$ with an acute apex and obtuse base with trichomes (Cassimiro 2011; Vasquez et al. 2018; Reflora 2020). The Pleurothyrium cuneifolium tropical tree species is 19 to $30 \mathrm{~m}$ tall with a trunk diameter of 30 to $80 \mathrm{~cm}$ and a cylindrical shape. It is a sciophyte tree species found in primary forests with high and constant rainfall and clayey-loamy fertile and well drained soils. The outer bark is a brown-cream color, with circular to elliptical lenticels that are 4 to $5 \mathrm{~mm}$ diameter and a dark brown color (OSINFOR 2015).

The Meliaceae family is represented by the Cedrela fissilis tree, which has a height of 20 to $35 \mathrm{~m}$ and a trunk diameter of 50 to $100 \mathrm{~cm}$, with a cylindrical shape and buttresses up to $1 \mathrm{~m}$ at the base. The outer bark is 1 to $2 \mathrm{~cm}$ thick, with a fissured light reddish-brown coloration; the inner bark is a pinkish to light cream color, with a slight characteristic onion 
odor. Cedrela odorata tress are 20 to $35 \mathrm{~m}$ tall and have a trunk diameter of 10 to $20 \mathrm{~cm}$, with a straight and cylindrical shaft with $1.50 \mathrm{~m}$ buttresses at the base. The outer skin is light grayish brown, with cracks in the longitudinal plates, a pinkish inner skin and a characteristic odor (OSINFOR 2018; SERFOR 2020b).

The Moraceae family is represented by the Brosimum alicastrum tree, which are 40 $\mathrm{m}$ tall and have a trunk diameter of $150 \mathrm{~cm}$, with buttresses at the base. The outer bark is light green and is either smooth or has superficial cracks. The inner bark is yellowish and excretes a white and sticky latex. Poulsenia armata trees are 25 to $40 \mathrm{~m}$ tall, with a trunk diameter of 60 to $100 \mathrm{~cm}$ and 4 to $5 \mathrm{~m}$ tabular roots. They are found in evergreen and subevergreen forests. The outer bark is fissured, with a brownish brown or brownish gray color, while the inner shell is pale brown. The tree excretes a yellowish white latex with the consistency of chewing gum when dried. The Lecythidaceae family is represented by two species of Cariniana spp. tree, Cariniana decantra and Cariniana domestica. They have a height of $30 \mathrm{~m}$ and a trunk diameter of 70 to $90 \mathrm{~cm}$ and are found in very humid premontane and tropical humid forests. The outer bark is a dark brown color with fibrous rhytidoma, either smooth or fissured, that are $4 \mathrm{~cm}$ thick. The inner bark is a creamy white color with a fibrous appearance and exudes a rancid oily smell (Custodio 2005; Cassimiro 2011; Olivia and Zerpa 2018; Lava et al. 2019).

Belonging to the Euphorbiaceae family, Hura crepitans trees are 20 to $40 \mathrm{~m}$ tall, with a trunk diameter of 1 to $2 \mathrm{~m}$ and have a straight and cylindrical shape with buttresses up to $1.5 \mathrm{~m}$. The outer bark is gray, with conical and pointed spines, while the inner bark is yellowish white, with caustic and poisonous latex. The Bignoniaceae family is represented by the Jacaranda copaia tree, which is 30 to $35 \mathrm{~m}$ tall, and has a trunk diameter of 60 to $75 \mathrm{~cm}$, with a generally straight base. The outer bark is a whitish brown color, with moderate fissuring depending on the tree age. The inner bark is a yellowish to whitish color that oxidizes to brown, and is homogeneous, grainy (Mallque and Kikata 1994; Reynel et al. 2003; OSINFOR 2018; SERFOR 2020b).

The Malvaceae family is represented by the Matisia bicolor tree, with a height of 15 to $35 \mathrm{~m}$ and a trunk diameter of 40 to $90 \mathrm{~cm}$, that is slightly enlarged at the base, with buttresses up to $1 \mathrm{~m}$ in height. The outer bark is smooth, with a light brown color and is granular. The inner bark is yellow (OSINFOR 2018). The Myristicaceae family is represented by the Otoba spp. tree, that are $35 \mathrm{~m}$ tall and have a trunk diameter of 60 to 80 $\mathrm{cm}$, with a straight and cylindrical shape. They have a reddish-brown outer bark, with small cracks, and a pinkish whitish inner bark with transparent reddish exudation with an astringent flavor (Cassimiro 2011; SERFOR 2020b).

The Combretaceae family is represented by the Terminalia oblonga tree, which is $45 \mathrm{~m}$ tall and has a trunk diameter of 50 to $100 \mathrm{~cm}$, with a monopodic, cylindrical shape. It is commonly found below $600 \mathrm{~m}$ above sea level, with high rainfall and a marked dry season. The lamellar and smooth outer bark is a yellow light brown to greyish color, with 6 to $9 \mathrm{~cm}$ long fissures due to the detachment of the rhytidome (Mallque and Kikata 1994; Custodio 2005; OSINFOR 2018; Mendonza et al. 2020). The Burseraceae family is represented by the Tetragastris altíssima tree, which are $30 \mathrm{~m}$ tall and have a trunk diameter of $80 \mathrm{~cm}$. They have a straight shape, with buttresses absent or up to $50 \mathrm{~cm}$ at the base, and resin extraction is possible (Custodio 2005).

\section{Common Names and Species Identification via Wood Anatomical Features}

The results of the botanical identification of the Lauraceae species, based on the anatomical structure analysis, indicated the same common name was used for different tree 
species due to their general characteristics similarities. The most highlighted example was "moena amarilla" for Ocotea aciphylla (with vasicentric axial parenchyma, tilosis, and distinct growth rings) (Fig. $2 \mathrm{~K} 1,2$ ) and Persea areolatocostae (with sparse parenchyma and indistinct growth rings) (Fig. $2 \mathrm{N1}$,2). However, Pleurothyrium brochidodromum is considered the true "moena amarilla", while Oliva and Zerpa (2018) state that Moena amarilla is a different species, Aniba puchury-minor (Mart.) Mez., which belongs to the Lauraceae family (Cassimiro 2011).

Likewise, "sachapalta" is the common name applied to Ocotea spp. (Fig. 2, J1,2), as well as to $O$. argyrophylla, O. gracilis, and Persea caerulea (Cassimiro, 2011; SERFOR 2020b). Similar to "moena negra", which was identified as Pleurothyrium cuneifolium (Fig. 2 O1,2), it was the same genus as "moena amarilla", but has a darker wood, tilosis, and dark gum filling the vessels.

In addition, "moena amarilla, moena rosada, moena, moena blanca, and moena alcafor" are common names applied to the genus Aniba Aubl., whereas "roble blanco, sacha moena, isphinguillo, yanay and moena" are applied to Ocotea wood, showing the difficulties of their identification (SERFOR 2020b). In addition, "moena rosada" is applied to Ocotea leucoxylon (Fig. 2 L1,2) and Aniba roseodora, which is considered a vulnerable species whose essential oil is used for perfumery. The "moena blanca" wood (as shown in Fig. 2 A1,2), which was found to be Aniba panurensis by Cassimiro (2011) is also called "moena canfora" (SERFOR 2020a). The ecological trends of the tropical tree species occurring in the Brazilian Atlantic Forest show that the Lauraceae species can be grouped by the anatomical characteristics of the wood expressing a specific anatomical pattern (Barros et al. 2006).

In the Meliaceae family, there are similarities in the wood anatomical structure, although in "cedro agua", i.e., Cedrela fissilis, the tree-rings are delimited by axial channels and fibrous areas, while in "cedro", i.e., C. odorata, the tree-rings are delimited by thin bands of marginal parenchyma (Fig. 2 D1-2; E1-2) (Santini Jr et al. 2021). Of the 20 timber tree species, $C$. odorata was included in the CITES Appendix III as vulnerable and is under surveillance (SERFOR 2020b). In the tropical rainforests countries, such as those in Brazil, Peru, Colombia, Bolivia, Venezuela, etc., cedar trees are overexploited, and are at extinction risk and biodiversity loss, due to the wood quality and its numerous applications (Martinelli and Moraes 2013).

Belonging to the Moraceae family, Brosimum alicastrum wood (as shown in Fig. 2 B1,2), known as "congona" and "manchinga", has a characteristic yellow color and aliform axial parenchyma (SERFOR 2020a). However, the species can be easily confused and marketed in the Peruvian forest as "Panguana" (Brosimum utile (Kunth) Oken.) e Marupa (Simarouba amara Aubl.), being differentiated primarily by the presence of axial parenchyma with shorter linear extensions and by the lighter color and lower concentration of vessels, respectively (Olivia and Zerpa 2018).

In the Lecythidaceae family, the names "cachimbo" and "cachimo colorado" (Olivia and Zerpa, 2018) are characteristic of the Cariniana sp. trees (C. decantra, $C$. domesticata, and C. estrellensis) (Mallque and Kikata 1994). Due to the macroscopic anatomical similarity of these species, it is necessary to have botanical support for the precise identification of the species, whose primary characteristic is a typical reticulated parenchyma and the presence of tilosis (Fig. 2 C1,2).

In the Malvaceae family, the wood called "sapote", common in the wood trade in Peru, was identified as Matisia bicolor (Fig. 2 I,1,2), which has a distinctive diffuse aggregated parenchyma. This species can be confused by its common name, despite the 
anatomical differences, with Matisia cordata Bonpl. and Capparis scabrida Kunth Capparaceae family, which is considered extremely vulnerable due to overexploitation (Rodriguez et al. 2007; SERFOR 2020a; Olivia and Zerpa 2018).

"Cumala", "aguanillo" and "Banderilla" are the common names given to species of the genus Otoba Aubl in the Peruvian forest, while the Otoba parviflora (Markgraf) A. H. Gentry and Otoba glycicarpa (Ducke) W.A. Rodrigues \& T.S. Jaram species belong to the Myristicaceae family (as shown in Fig. 2 M1,2). These species are characterized by the sparse parenchyma and indistinct growth rings, although these common names are also applied to the Iryanthera, Ostepphoeum and Virola species despite of the difference in the wood anatomy (Cassimiro 2011; SERFOR 2020b). However, the species are called "aguanillo" and "Banderilla" as well (Olivia and Zerpa 2018).

From the Moraceae family, Poulsenia armata wood (as shown in Fig. 2 P1,2) was known as "Lanchan" and, eventually known as "Lanchama" and is recognized by its vasicentric or aliform paratracheal parenchyma. However, Schizolobium amazonicum wood (as shown in Fig. 2 R1,2), from the Fabaceae family, also has typical aliform paratracheal parenchyma, but is known as "pino chuchu", as well as "huilca, pashaco, falso pino, and pino rojo" (Cassimiro 2011; SERFOR 2020b).

Among the wood samples collected, one species was identified as "palo leche", Couma macrocarpa, from the Apocynaceae family. However, the wood that the anatomical exam confirmed as "palo carton" was actually Jacaranda copaia (as shown in Fig. 2 H1,2), which had a light white-yellow and aliform paratracheal parenchyma, that was sometimes confluent. Couma macrocarpa wood, i.e., "paloleche, leche leche, or leche caspi" wood, presents diffuse apotracheal axial parenchyma (Santini Jr. et al. 2021).

\section{Comparative Tree Species Wood Anatomy}

The comparation of the wood anatomical features allowed the identification of 20 woody tree species, that belonged to 10 families. The identified tree species showed a common anatomical characteristic, i.e., the growth layers were distinct and delimited by differentiated xylem tissues. The boundaries of the growth layers are characteristic of each taxonomic group, e.g., the marginal longitudinal parenchyma and semi-ring vessels in Cedrela fissilis, the layers of thick-walled fibers in Hura crepitans, and the greater distance of the reticulated parenchyma lines in Cariniana spp. trees. The growth layers in the trunk xylem of the tropical tree-species are, in general, related to the cambial meristem seasonality, which is influenced by climatic seasons, i.e., alternating periods of soil water availability and stress. The intrinsic physiological process of the tree species, associated with climatic factors, exerts influence on the phenological phases, from the deciduous leaf during the dry period and the sprouting and restoration of the tree canopy during the rainy season. Marcelo-Peña et al. (2020), working with 183 species of Peruvian forest trees, noted that 42 species $(23 \%)$ had growth rings with high distinction, 60 species $(33 \%)$ had moderately visible rings, 60 species $(33 \%)$ had poor ring distinction, and 21 species $(11 \%)$ had absent or indistinct growth rings.

In relation to the xylem vessels of the 20 tree species, there are cluster pattern variations, with a predominance of solitary and multiple vessels (75\%), followed by solitary vessels (25\%). This climate type is characterized by high temperatures in the summer and mild ones in the winter (Nimer 1989; Alves and Angyalossy-Alfonso 2000). In addition, $90 \%$ of the tropical species studied had diffuse porosity while $10 \%$ had semiring porosity.

The xylem vessels were predominantly blocked by tyloses, gums, and resins, which 
were detectable in the cross (pore filled) and tangential longitudinal (vascular lines) orientations. Known as extractives, the substances from the secondary metabolism of the trees as well as the characteristics of the heartwood region of the non-functional xylem, in general, provide natural resistance to xylophagous organisms. In some species, the presence of gums, resins, and tyloses are considered important characteristics for the identification of tropical species, e.g., Lauraceae, which have their anatomical structure in their oil producing channels.

The parenchyma tissues of the same family tree species xylem showed characteristic morphological differences related to physiology and taxonomy. The most expressive type of longitudinal parenchyma was classified as vasicentric or aliform paratracheal longitudinal, eventually confluent, and scarce $(65 \%)$. The apotracheal longitudinal parenchyma diffused in aggregates (15\%), in marginal bands (10\%) and in reticulate and thicker bands (5\%). According to Duarte et al. (2021) the presence of visible axial parenchyma only is responsible for the segregation of several tropical species. In Brazil, Alves and Alfonso (2002) emphasized the relationships between the presence of paratracheal parenchyma in warmer climates and apotracheal parenchyma in colder climates.

\section{Identification Key of the Forest Tree Species via Wood Anatomical Characteristics}

The Amazon rainforests are well known for their diversity of plant and animal species, and, in particular, for their abundance of tree species. The identification of the wood producing tree species along the production chain is possible by utilizing the wood anatomy, based on the types of cells and tissue diversity. It should be noted that important tree families from tropical forests, e.g., Lauraceae, require further research, due to the high species diversity and usual application of similar trade names to different species. The description of the wood anatomical structure allows them to be grouped into taxonomic groups with common characteristics, following the identification specific of each species. This principle underlies the constructed identification keys of the tropical tree species using the wood anatomical structure, while some are available in the specialized literature (Florsheim et al. 2020; Santini Jr et al. 2021). Thus, based on the 20 forest tree species, whose wood was used as a tool to provide the species identification, a novel identification key was created in the present work. This identification key will allow the inclusion of new wood species from the Peruvian "Selva Central" and can also be applied as a basis for the development of a new identification method via artificial intelligence (Fabijańska et. al. 2021).

\section{Key for Wood Macroscopic Identification}

I. Wood with a distinct axial parenchyma at simple view

Wood with axial parenchyma associated with the vessels (paratracheal)

\section{A.1. Vasicentric axial parenchyma}

1a. Different growth layers

1b. Indistinct growth layers

2a. Heartwood has light yellow coloration, vasicentric axial parenchyma and distinct growth layer: Enterolobium schomburgkii

2b. Heartwood with other coloration and distinct growth layers 
3a. Heartwood is reddish brown, with distinct growth layers, diffuse porosity in a diagonal arrangement, and vasicentric axial parenchyma: Ocotea spp.

3 b. Heartwood is a yellow color, with distinct growth layers delimited by fibrous zones, a diffuse porosity, and predominantly solitary vessels in a diagonal arrangement: Ocotea aciphylla

4a. Heartwood is a brown color, with indistinct growth layers, diffuse porosity in a diagonal arrangement, and vasicentric axial parenchyma: Poulsenia armata

4b. Heartwood is dark brown, with distinct growth layers delimited by fibrous zones, moderately heavy wood, and vascentric axial parenchyma: Pleurothyrium cuneifolium

\section{A.2. Aliform axial parenchyma}

1a. Wood light yellow color

1b. Wood strong yellow color

2a. Heartwood is a light-yellow color, with distinct growth layers, diffuse porosity, aliform parenchyma with linear extension, and is confluent at times: Brosimum alicastrum

2b. Heartwood is a strong yellowish color, with distinct growth layers, diffuse porosity, and aliform axial parenchyma with angular extension

3a. Heartwood is a strong yellowish color, with distinct growth layers, diffuse porosity, and aliform axial parenchyma with lozenge-shaped extensions: Schizolobium amazonicum. 3b. Heartwood is a strong yellowish color, distinct growth layers, diffuse porosity, aliform parenchyma with lozenge-shaped extensions, and is confluent at times: Terminalia oblonga

\section{A.3. Marginal axial parenchyma and/or bands}

1a. Axial parenchyma in marginal lines

1b. Banded axial parenchyma, strong yellowish color, and distinct growth layers:

Pterocarpus spp.

2a. Heartwood is reddish, distinct growth layers delimited by narrow bands of marginal parenchyma, vessels of smaller diameter in tree-ring boundaries: Cedrela fissilis

2b. Heartwood is reddish, distinct growth layers delimited by large bands of marginal parenchyma, vessels of larger diameter in tree-ring boundaries: Cedrela odorata

B. Woods with axial parenchyma not associated with vessels (apotracheal)

1a. Heartwood is a yellowish wood

1b. Heartwood is another color

2a. Yellowish heartwood, distinct growth layers, radially disposed vessels, aggregated diffuse apotracheal parenchyma, and vessels sometimes have tyloses: Hura creptans

$2 \mathrm{~b}$. Heartwood is another color, with distinct growth layers, and apotracheal parenchyma (3)

3a. Heartwood is a brown yellowish, reticulated parenchyma: Cariniana spp.

3b. Heartwood is a yellow whitish, diffuse aggregated apotracheal parenchyma: Matisia bicolor. 
Table 2. Tree Species Identified by General and Wood Macroscopic Characteristics

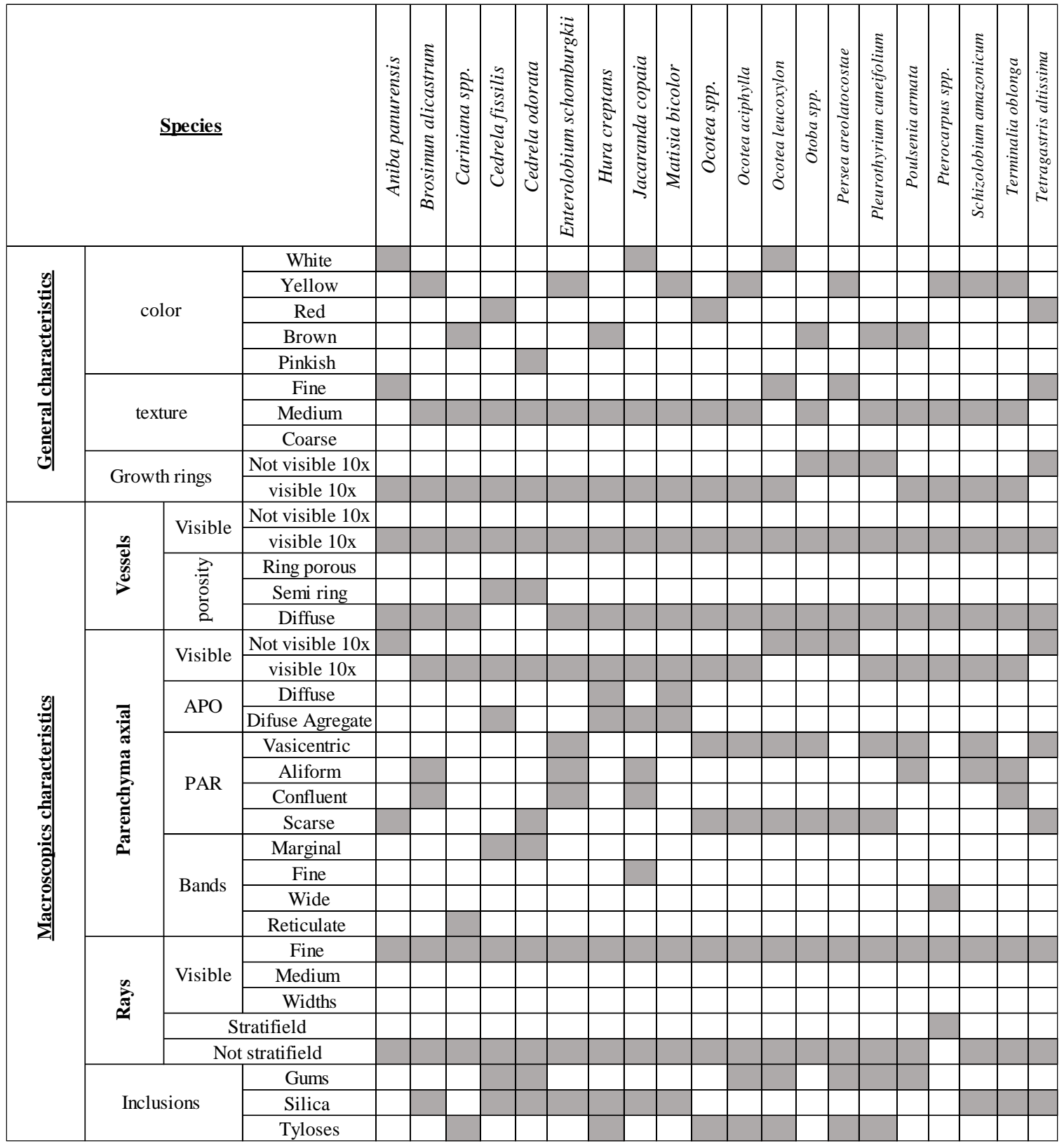

II. Woods with distinct axial parenchyma under lens (10x)

1a. Distinct growth layers and heartwood is a whitish color

1b. Distinct growth layers and heartwood is another coloration

2a. Heartwood is a whitish color, with distinct growth layers, diffuse porosity in a diagonal arrangement, and scarce paratracheal parenchyma: Aniba panurensis

$2 \mathrm{~b}$. Heartwood is a whitish color, with distinct growth layers, and distinct linear aliform parenchyma under lens (10x): Jacaranda copaia

3a. Heartwood is a pinkish color, with distinct growth layers, diffuse porosity in a diagonal 
arrangement, and sparse axial parenchyma: Ocotea leucoxylon 3b. Indistinct growth layers

4a. Heartwood is an orange color, with undistinguished growth layers, moderately heavy wood, and sparse axial parenchyma: Tetragastris altissima 4b. Heartwood is another color, with indistinct growth layers

5a Heartwood is light-yellow, with indistinct growth layers, diffuse porosity in a diagonal arrangement, mostly solitary vessels, and sparse and indistinct axial parenchyma under lens (10x): Persea areolatocostae.

5 b. Heartwood is a brown color, with indistinct growth layers, diffuse porosity in a diagonal arrangement, and sparse axial parenchyma: Otoba spp.
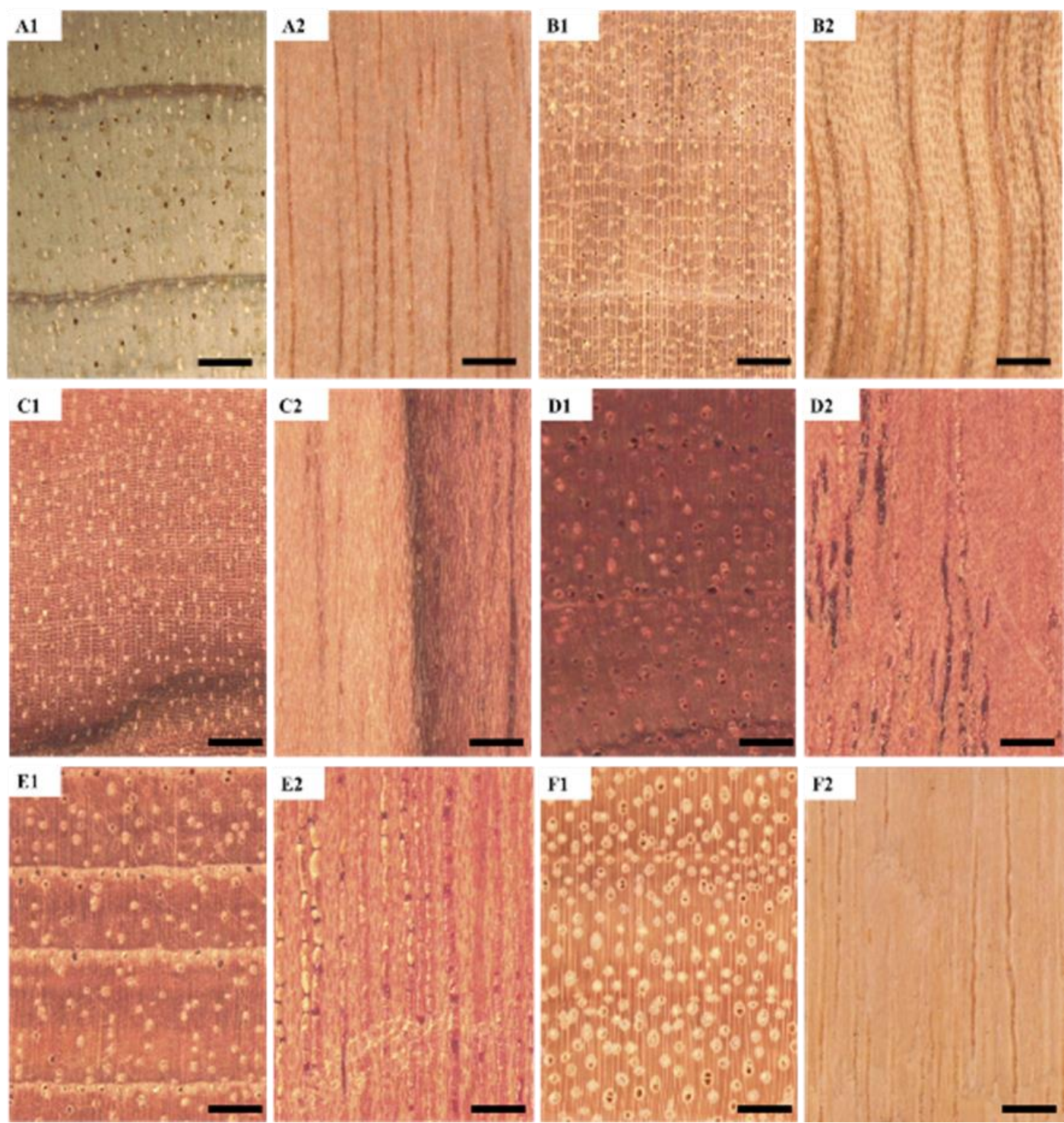

Fig. 2. Wood cross (10) and longitudinal tangential (2) sections of the 20 tree species: Aniba panurensis (A1 and A2); Brosimum alicastrum (B1 and B2); Cariniana spp. (C1 and C2); Cedrela fissilis (D1 and D2); Cedrela odorata (E1 and E2); and Enterolobium schomburgkii (F1 and F2) Note: Bar is $1000 \mu \mathrm{m}$. 

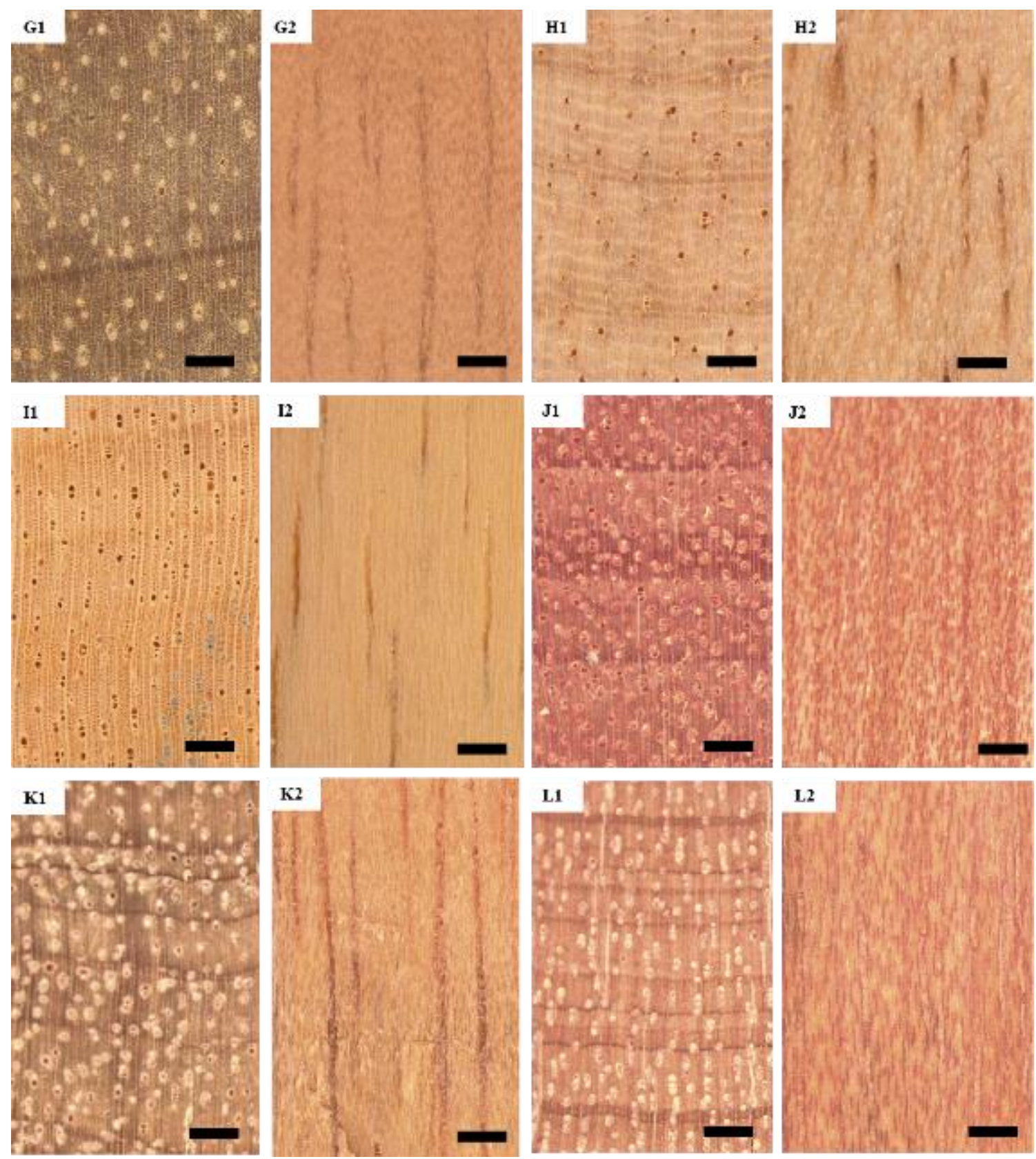

Fig. 2 (cont.) Wood cross (10) and longitudinal tangential (2) sections of the 20 tree species: Hura creptains (G1 and G2); Jacaranda copaia (H1 and H2); Matisia bicolor (I1 and I2); Ocotea spp (J1 and J2); Ocotea aciphylla (K1 and K2); and Ocotea leucoxylon (L1 and L2). Note: Bar is $1000 \mu \mathrm{m}$ 

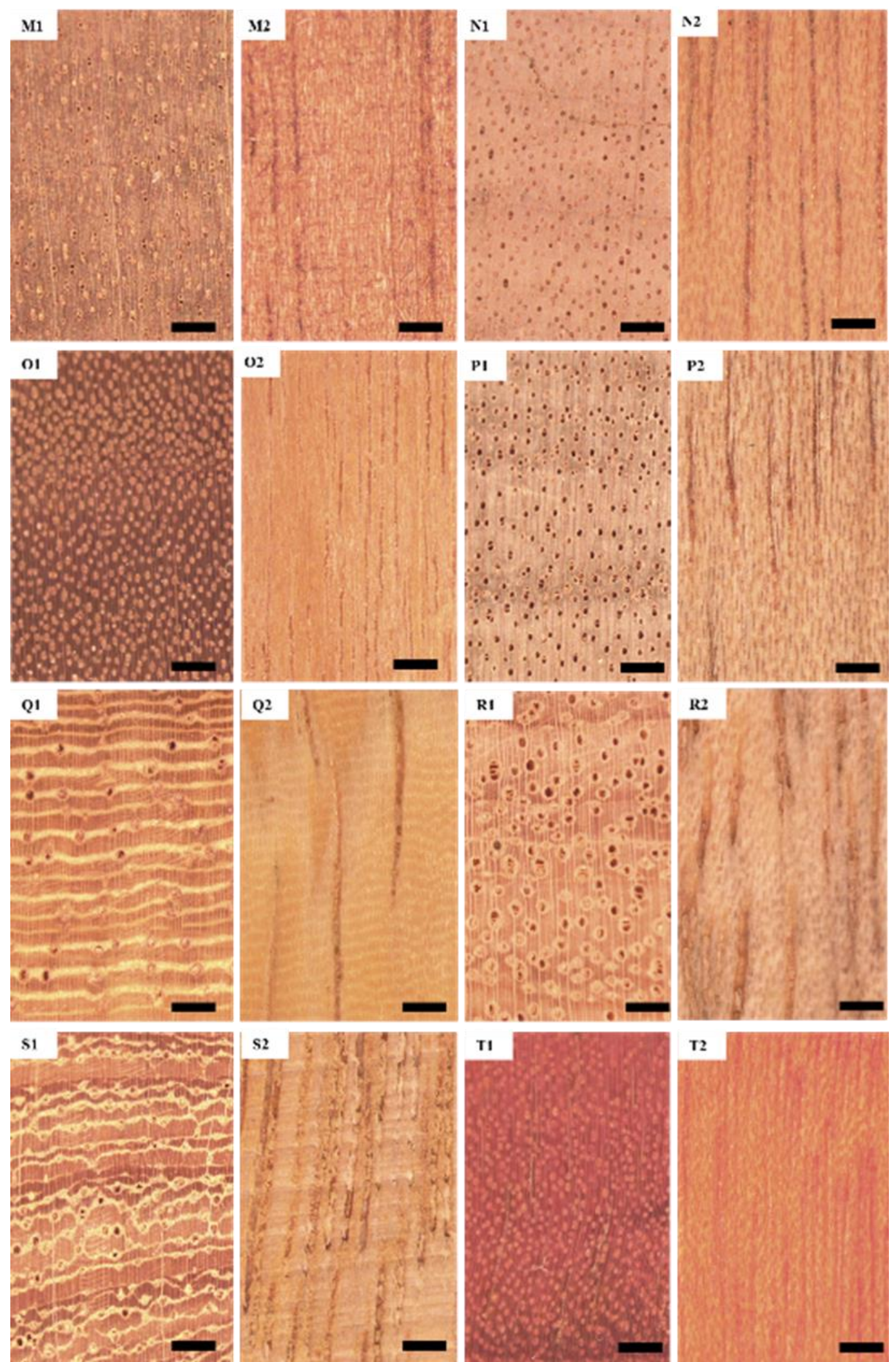

T2

Fig. 2 (cont.) Wood cross (10) and longitudinal tangential (2) sections of the 20 tree species: Otoba spp (M1 \& M2); Persea areolatocostae (N1 \& N2); Pleurothyrium cuneifolium (O1 \& O2); Poulsenia armata (P1 \& P2); Pterocarpus spp. (Q1 \& Q2); Schizolobium amazonicum (R1 \& R2]); Terminalia oblonga (S1 \& S2); and Tetragastris altissima (T1 \& T2) Note: Bar is $1000 \mu \mathrm{m}$. 


\section{CONCLUSIONS}

1. The primary wood-producing tree species from the tropical "Selva Central" Peruvian forests are likely to be identified by their macroscopical anatomical features.

2. Twenty tree species were identified, belonging to 17 genera, majority constituted by Lauraceae and Fabaceae, followed by Moraceae, Meliaceae, Lecythidaceae, Euphorbiaceae, Bignoniaceae, Myristicaceae, Combretaceae, and Burseraceae families.

3. The identification key based on the wood color and macroscopic anatomical structures allowed for species identification. Representative tree families, e.g., Lauraceae and Meliaceae, require further research, due to the high species diversity in the Peruvian tropical Amazon forests, as well as in neighboring countries

4. The results constitute an important stage for the application of new methodologies, i.e., convolutional neural networks for woody species identification. This methodology is essential for the assembly of national and international databases comprising of the anatomical characteristics of tropical tree species, with the aim of monitoring and controlling illegal timber trade, for sustainable forest management and genetic conservation.

\section{ACKNOWLEDGMENTS}

This research was supported by the Project Concytec - Banco Mundial, through its executing unit is the Fondo Nacional de Desarrollo Científico, Tecnológico y de Innovación Tecnológica (FONDECYT) (Project No. 043-2019-FONDECYTBMINC.INV). A special thanks to the entire team of the research project "MaderApp: Un aplicativo móvil para el reconocimiento automático y en tiempo real de especies maderables comerciales para combatir la tala ilegal en Selva Central, Perú".

\section{REFERENCES CITED}

Alves, E. S., and Angyalossy-Alfonso, V. (2000). "Ecological trends in the wood anatomy of some Brazilian species. 1. Growth rings and vessels," IAWA Journal 21(1), 3-30. DOI: 10.1163/22941932-90000233

Alves, E. S., and Angyalossy-Alfonso, V. (2002). "Ecological trend in the wood anatomy of some Brazilian species. 2. Axial parenchyma, rays and fibres," IAWA Journal 23(4), 391-418. DOI: 10.1163/22941932-90000311

Barros, C. F., Marcon-Ferreira, M. L., Callado, C. H., Lima, H. R. P., Cunha M. d., Marquete, O., and Costa, C. G. (2006). "Ecological trends in wood anatomy of tree species at Poço das Antas Biological Reserve, Rio de Janeiro, Brazil, Brasil," Rodriguésia 57(3), 443-460. DOI: 10.1590/2175-7860200657305

Carlquist, S. (2001). Comparative Wood Anatomy: Systematic, Ecological, and Evolutionary Aspects of Dicotyledon Wood, Springer, Berlin, Germany.

Cassimiro, I. G. (2011). Atlas de Maderas Selva Central [Central Jungle Wood Atlas], National University of the Center of Peru, Huancayo, Peru.

Claudon, J.-C. (2020). "Elements for the biennial review and assessment of the world

Ferreira et al. (2021). "Identification of Amazon trees," BioResources 16(4), 7161-7179. 7176 
timber situation 2019-2020," (https://www.itto.int/ittc-56/day5/), accessed 12 January 2021.

Coradin, V. T. R., and Muñiz, G. I. B. d. (1992). Normas de Procedimentos em Estudos de Anatomia de Madeira: Angiospermae e Gymnospermae [Rules of Procedure in Wood Anatomy Studies: Angiospermae and Gymnospermae] (v. 15.), Forest Products Laboratory - Technical Series, Brasília, Brazil.

Coradin, V. T. R., Camargos, J. A. A., Pastore, T. C. M., and Christo, A. G. (2010). Brazilian Commercial Timbers: Interactive Identification Key Based on General and Macroscopic Features (CD-ROM), Brazilian Forest Service, Forest Products Laboratory: Brasília, Brasília, Brazil.

Custodio, M. C. (2005). Maderas Para Pisos [Floor Woods], Universidad Nacional Agraria de la Molina, Distrito de Lima, Peru.

Custodio, M. C. (2015). Atlas Anatómico de Maderas del Perú [Anatomical Atlas of Maderas del Peru], Universidad Nacional Agraria de la Molina, Distrito de Lima, Peru.

de Lima, L. S., Merry, F., Soares-Filho, B., Rodrigues, H. O., Damaceno, C. d. S., and Bauch, M. A. (2018). "Illegal logging as a disincentive to the establishment of a sustainable forest sector in the Amazon," PloS One 13(12), 1-21. DOI:

10.1371/journal.pone.0207855

Dormontt, E. E., Boner, M., Braun, B., Breulmann, G., Degen, B., Espinoza, E., Gardner, S., Guillery, P., Hermanson, J. C., Koch, G., et al. (2015). "Forensic timber identification: It's time to integrate disciplines to combat illegal logging," Biological Conservation 191, 790-798. DOI: 10.1016/j.biocon.2015.06.038

Duarte, P. J., Borges, C. C., Ferreira, A. C., Cruz, T. M., de Souza, W. R. Q., and Mori, F. A. (2021). "Anatomical identification of tropical woods traded in Lavras, Brazil," Journal of Tropical Forest Science 33(1), 95-103. DOI: 10.26525/jtfs2020.32.4.95

Fabijańska, A., Małgorzata, D., and Barniak, J. (2021). "Wood species automatic identification from wood core images with a residual convolutional neural network," Computers and Electronics in Agriculture 181, 1-13. DOI:

10.1016/j.compag.2020.105941

Florsheim, S. M. B., Ribeiro, A. P., Longui, E. L., de Andrade, I. M., Sonsin-Oliveira, Chimelo, J. P., Soares, R. K., Gouveia, T. C., and Marques, V. N. (2020). Macroscopic Identification of Commercial Wood in the State of São Paulo, Instituto Florestal, São Paulo, Brazil.

Gasson, P. (2011). "How precise can wood identification be? Wood anatomy's role in support of the legal timber trade especially cites," IAWA Journal 32(2), 137-154. DOI: $10.1163 / 22941932-90000049$

Gasson, P., Baas, P., and Wheeler, E. (2011). "Wood anatomy of Cites - Listed tree species,” IAWA Journal 32(2) 155-198. DOI: 10.1163/22941932-90000050

Hoadley, R. B. (1990). Identifying Wood: Accurate Results with Simple Tools, Taunton Press, Newtown, CT.

Lava, E., Pacheco, C., Rivero, M., Trujillo, G., Senosaín, Y., and Lopez, F. (2019). Catálogos de Maderas, Comisión de Promoción del Perú para La Exportación y el Turismo, Distrito de Lima, Peru.

Linares, H. D., and Ramos, C. N. (2011). Dendrologia Tropical: Estudio y Caracterizacion Dendrologica de las Principales Especies Forestales de la Amazonia Peruana [Tropical Dendrology: Study and Dendrological Characterization of the Main Forest Species of the Peruvian Amazon], Alfa Servicios Gráficos SRL, Cusco, 
Peru.

Maguiña, E. V. G. (2008). Identificación organoléptica y macroscópica de maderas comerciales: Serie I: Competencias Básicas para la Producción Industrial de Muebles de Madera [Organoleptic and macroscopic identification of commercial woods: Series I: Basic Competences for the Industrial Production of Wooden Furniture], CITEmadera, Lima, Peru.

Mallque, M. A., and Kikata, Y. (1994). Atlas de Maderas del Peru [Wood Atlas of Peru], Universidad Nacional Agraria de la Molina, Distrito de Lima, Peru and Nagoya University, Nagoya, Japan.

Marcelo-Peña, J. L., Roig, F. A., Goodwin, Z. A., and Tomazello-Filho, M. (2020). "Characterizing growth rings of Peru: A wood anatomical overview for potential applications in dendroecological-related fields," Dendrochronologia 62, 1-13. DOI: 10.1016/j.dendro.2020.125728

Martinelli, G., and Moraes, A. M. (2013). Livro Vermelho da Flora do Brasil [Red Book of Flora of Brazil], Instituto de Pesquisas Jardim Botânico do Rio de Janeiro, Rio de Janeiro, Brazil.

Mendoza, A. M., Martínez, R. V., Gonzales, R. R., Phillips, O. L., Baker, T. R., Linares, H. D., Pickavance, G. C., Vargas, P. N., Valverde, F. C., Janovec, J. P., et al. (2020). Primer Catálogo de los Árboles de la Amazonia de Madre de Dios [First Catalogue of the Amazonian Trees Species of Madre De Dios, Peru], Universidad Andina del Cusco, Cusco, Peru.

MINAM, 2015: Ministerio del Ambiente: Mapa nacional de cobertura vegetal: memoria descriptiva [National Vegetation Cover Map: Descriptive Memory] Ministerio del Ambiente, Dirección General de Evaluación, Valoración y Financiamiento del Patrimonio Natural. - Lima, Perú.

Nimer, E. (1989). Climatologia do Brasil. Instituto Brasileiro de Geografia e Estatística, Rio de Janeiro [Climatology of Brazil. Brazilian Institute of Geography and Statistics, Rio de Janeiro]

Oliva, J. U., and Zerpa, I. M. (2018). Guia para la identificación de la madera de 50 especies forestales del Peru [Guide to the wood identification of 50 forest species in Peru]. Centro de Innovación Productiva y Transferencia Tecnologica de la Madera, CITEmadera, Lima, Perú.

OSINFOR (2015). Fichas de Identificación de Especies Forestales Maderables de la Selva Central [Identification Sheets for Timber Forest Species of the Central Jungle], Vistay Publicidad E.I.R.L., Lima, Perú.

OSINFOR (2017). Fichas De Identificación de Especies Forestales Maderables y Silvicultura Tropical [Identification Sheets of Timber Forest Species and Tropical Silviculture], Vistay Publicidad E.I.R.L., Lima, Perú

OSINFOR (2018). Fichas de Identificación de Especies Forestales Maderables y Silvicultura Tropical [Identification Sheets of Timber Forest Species and Tropical Silviculture], Vistay Publicidad E.I.R.L., Lima, Perú

Penagos, J. C., and Madriñán, S. (2015). "Aniba panurensis (Meisn.) Mez," (http://catalogoplantasdecolombia.unal.edu.co/en/resultados/especie/Aniba\%20panur ensis/), accessed 21 June 2021.

Reflora (2020). "Ocotea leucoxylon (Sw.) Laness," (http://floradobrasil.jbrj.gov.br/reflora/floradobrasil/FB17947), accessed 19 June 2021.

Reynel, C., Pennington, T. D., Pennington, R. T., Flores, C., and Daza, A. (2003). 
Árboles útiles de la Amazonia Peruana: Un Manual con Apuntes de Identificación, Ecología y Propagación de las Especies [Useful Trees of the Peruvian Amazon: A Manual with Notes on Identification, Ecology and Propagation of Specie], Lima (Perú) Tarea Gráfica Educativa, Lima, Perú.

Rodríguez, E. F. R., Bussmann, R. W., Alfaro, S. J. A., Medina, S. E. L., and Rosario, J. B. (2007). "Capparis scabrida (Capparaceae) Una especie del Perú y Ecuador que necesita planes de conservación urgente [A species from Peru and Ecuador that needs urgent conservation plans]," Amaldoa 14(2), 29-282.

Ruffinatto, F., Crivellaro, A., and Wiedenhoeft, A. C. (2015). "Review of macroscopic features for hardwood and softwood identification and a proposal for a new character list," IAWA Journal 36(2), 208-241. DOI: 10.1163/22941932-00000096

Santini, Jr, L., Florsheim, S. M. B., and Tomazello-Filho, M. (2021). Anatomia e Identificação da Madeira de 90 Espécies Tropicais comercializadas em São Paulo [Wood Anatomy and Identification of 90 Tropical Species commercialized in São Paulo], Atena Editora, Ponta Grossa, Brasil.

SERFOR (2016). "Peru define prioridades de Gobernanza Forestal y Reducción de Tala y comercio Ilegal de madera [Peru defines priorities for Forest Governance and Reduction of Logging and Illegal timber trade]," (https://www.serfor.gob.pe/ portal/noticias/negocios-sostenibles/peru-define-prioridades-de-gobernanza-forestaly-reduccion-de-tala-y-comercio-ilegal-de-madera), accessed on 7 January 2021.

SERFOR (2020a). Anuario Forestal y de Fauna Silvestre 2019 [Forest and Wildlife Yearbook 2019], Servicio Nacional Forestal y da Fauna Silvestre, Lima, Peru.

SERFOR (2020b). Manual para la Identificación Botánica de Especies Forestales de la Amazonía Peruana [Manual for the Botanical Identification of Forest Species of the Peruvian Amazon], Servicio Nacional Forestal y da Fauna Silvestre, Lima, Peru.

Spicer, R. (2014). "Symplasmic networks in secondary vascular tissues: Parenchyma distribution and activity supporting long-distance transport," Journal of Experimental Botany 65(7), 1829-1848. DOI: 10.1093/jxb/ert459

TROPICOS (2021). "Missouri botanical garden," (http://www.tropicos.org), accessed 10 June 2021.

Vásquez, R., Rojas, R., Monteagudo, A., Valenuela, L., and Huamantupa, I. (2018). "Catálogo de los árboles de Peru [Catalogue of trees of Peru]," Rev. Qeuña 9(1), 582.

Vlam, M., de Groot, G. A., Boom, A. Copini, P., Laros, I., Veldhuijzen, K., Zakamdi, D., and Zuidema, P. A. (2018). "Developing forensic tools for an African timber: Regional origin is revealed by genetic characteristics, but not by isotopic signature," Biological Conservation 220, 262-271. DOI: 10.1016/j.biocon.2018.01.031

Wheeler, A., Baas, P., and Gasson, P. (1989). "IAWA list of microscopic features for hardwood identification," IAWA Journal 10(3), 219-332.

Wheeler, E. A., and Baas, P. (1998). "Wood identification - A review," IAWA Journal 19(3), 241-264. DOI: 10.1163/22941932-90001528

Zenid, G. J., and Ceccantini, G. C. T. (2012). Identificação Macroscópica de Madeiras [Wood Macroscopic Identification], Instituto de Pesquisas Tecnológicas de São Paulo, São Paulo, Brazil.

Article submitted: July 19, 2021; Peer review completed: August 28, 2021; Revised version received and accepted: September 5, 2021; Published: September 9, 2021. DOI: 10.15376/biores.16.4.7161-7179 